\title{
PENGARUH PERTANIAN, INDUSTRI, DAN JASATERHADAP PENINGKATAN PERTUMBUHAN EKONOMI DI KOTA PALOPO
}

\author{
Putu Edi Eriawan ${ }^{1}$, Muh. Yusuf Q ${ }^{2}$, Salju ${ }^{3}$ \\ Email: ${ }^{1)}$ putu@gmail.com, ${ }^{2)}$ yusufq@ stiem.ac.id ${ }^{3)}$ saljusanuddin68@gmail.com \\ ${ }^{1,3)}$ Prodi Ilmu Pembangunan, Sekolah Tinggi Ilmu Ekonomi Muhammadiyah Palopo \\ ${ }^{2)}$ Prodi Manajemen, Sekolah Tinggi Ilmu Ekonomi Muhammadiyah Palopo
}

\begin{abstract}
Abstrak
Penelitian ini bertujuan untuk mengetahui Pengaruh Pertanian, Industri, dan Jasa Terhadap Peningkatan Pertumbuhan Ekonomi DI Kota Palopo. Jenis penelitian yang dilakukan adalah penelitian deskriptif kuantitatif. Penelitian ini dilakukan dengan mengambil data langsaung di BiroPusat Statistik Kota Palopo (BPS). Jenis data yang yang digunakan dalam penelitian ini adalah data sekunder, pengumpulan data dilakukan secara langsung dari sumbernya. Metode analisis data menggunakan analisis deskriptif. Populasi dalam penelitian ini adalah semua jumlah pendapatan daerah dari pertanian, industri, dan jasa dalam kurung waktu 5 tahun terakhir (20112015). Metode analisis yang digunakan dalam penelitian untuk mengetahui pengaruh antar variabel adalah analisis regresi bergandadengan bantuan software spss 21 for windows untuk mengolah data. Hasil penelitian menunjukkan bahwa: Pertanian, Industri, dan Jasa berpengaruh signifikan terhadap peningkatan pertumbuhan ekonomi.
\end{abstract}

Kata kunci: Pengaruh Pertanian, Industri, dan Jasa Terhadap Peningkatan Pertumbuhan Ekonomi di Kota Palopo

\section{PENDAHULUAN}

Pertumbuhan ekonomi merupakan suatu masalah jangka panjang yang harus dilakukan oleh setiap negara. Dimana dalam suatu negara sangat diharapkan terjadinya pertumbuhan ekonomi tersebut. Pertumbuhan ekonomi yang pesat merupakan fenomena penting yang dialami dunia semenjak dua abad belakangan ini. Dalam periode tersebut dunia telah mengalami perubahan yang sangat nyata apabila dibandingkan dengan periode sebelumnya. Sampai abad ke 18 kebanyakan masyarakat di berbagai negara masih hidup pada tahap subsistem dan mata pencarian utama adalah dari mata pencaharian di sektor pertanian, perikanan dan perkebunan.

Ditinjau dari sudut ekonomi, perkembangan ekonomi dunia yang berlaku semenjak dua abad yang lalu menimbulkan dua efek penting yang sangat terlihat, yaitu pertama kemakmuran atau taraf hidup masyarakat makin meningkat dan masyarakat dapat menciptakan kesempatan kerja yang baru kepada penduduk yang terus bertambah jumlahnya.Perjalanan pertumbuhan ekonomi di Indonesia yang masih menonjol hingga saat ini salah satunya dari pendapatan pertanian. Sebagaian besar penduduk Indonesia bermata pencarian dalam ruang lingkup pertanian, namun pertanian hanya menyumbang 4\% dari PDB dunia. Sejarah Indonesia sejak masa kolonial sampai sekarang tidak dapat dipisahkan dari sektor pertanian dan perkebunan, karena sektor ini memiliki arti yang sangat penting dalam menentukan pembentukan berbagai realitas ekonomi dan sosial masyarakat di berbagai wilayah Indonesia.Sektor pertanian merupakan sektor yang mempunyai peranan strategis dalam struktur pembangunan perekonomian nasional. Berdasarkan pada latar belakang di atas, maka permasalahan dalam pembahasan ini yaitu 1) apakah sektor pertanian berpengaruh positif dan signifikan terhadap pertumbuhan ekonomi; 2)Apakah sektor industri berpengaruh positif dan signifikan terhadap pertumbuhan ekonomi; 3)Apakah sektor jasa berpengaruh positif dan signifikan terhadap pertumbuhan ekonomi. Dengan demikian tujuan penelitian ini yaitu 1) untuk mengetahuai apakah sektor pertanian berpengaruh signifikan terhadap pertumbuhan ekonomi di Kota Palopo; 2) untuk mengetahui apakah sektor industri berpengaruh signifikan terhadap pertumbuhan ekonomi di Kota Palopo; ) untuk mengetahui apakah sektor jasa berpengaruh signifikan terhadap pertumbuhan ekonomi di Kota Palopo. 


\section{TINJAUAN PUSTAKA}

\section{Pertumbuhan Ekonomi}

\section{Pengertian Pertumbuhan Ekonomi}

Pertumbuhan ekonomi merupakan perkembangan kegiatan dalam perekonomian yang menyebabkan barang dan jasa yang diproduksi dalam masyarakat bertambah dan kemakmuran masyarakat meningkat. Faktor-faktor yang mempengaruhi perekonomian Indonesia tidak terlepas dari permasalahan kesenjangan dalam pengelolaan perekonomian, dimana para pemilik modal besar selalu mendapatkan kesempatan yang lebih luas dibandingkan dengan para pengusaha kecil dan menengah yang kekurangan modal.Dalam peringatan nobel dijelasakan bahwa pengertian pertumbuhan ekonomi adalah sebagai "Kenaikan jangka panjang dalam kemampuan suatu negara untuk menyediakan semakin banyak jenis barang-barang ekonomi kepada penduduknya; kemampuan ini tumbuh sesuai dengan kemajuan tekonologi, dan penyesuaian kelembagaan dan ideologis yang diperlukannya".Dalam pengertian umum pertumbuhan ekonomi diartikan sebagai proses perubahan kondisi perekonomian suatu negara secara berkesinambungan menuju keadaan yang lebih baik selama periode tertentu. Pertumbuhan ekonomi dapat diartikan juga sebagai proses kenaikan kapasitas produksi suatu perekonomian yang diwujudkan dalam bentuk kenaikan pendapatan nasional. Pertumbuhan ekonomi hanyalah merupakan salah satu aspek saja dari pembangunan ekonomi yang lebih menekankan pada peningkatan output agregat khususnya output agregat per kapita. Pengertian pertumbuhan ekonomi memiliki tiga komponen, yaitu :

a. Pertumbuhan ekonomi suatu bangsa terlihat dari meningkatnya secara terus-menerus persediaan barang;

b. Teknologi maju merupakan faktor dalam pertumbuhan ekonomi yang menentukan derajat pertumbuhan kemampuan dalam penyediaan aneka macam barang kepada penduduk;

c. Penggunaan teknologi secara luas dan efisien memerlukan adanya penyesuaian di bidang kelembagaan dan ideologi sehingga inovasi yang dihasilkan oleh ilmu pengetahuan umat manusia dapat dimanfaatkan secara tepat. Teknologi modern misalnya, tidak cocok dengan corak/kehidupan desa, pola keluarga besar, usaha keluarga dan buta huruf.
Faktor-Faktor yang Mempengaruhi Pertumbuhan Ekonomi

Perekonomian dikatakan mengalami pertumbuhan apabila jumlah balas jasa riil terhadap penggunaan faktor-faktor produksi pada tahun tertentu lebih besar daripada tahun sebelumnya. Ada lima faktor yang mempengaruhi pertumbuhan ekonomi, yaitu :

a. Faktor Sumber Daya Manusia

Sama halnya dengan proses pembangunan, pertumbuhan ekonomi juga dipengaruhi oleh SDM. Sumber daya manusia merupakan factor terpenting dalam proses pembangunan, cepat lambatnya proses pembangunan tergantung kepada sejauhmana sumber daya manusianya selaku subjek pembangunan memiliki kompetensi yang memadai untuk melaksanakan prosespembangunan.

b. Faktor Sumber Daya Alam

Sebagian besar negara berkembang bertumpu kepada sumber daya alam dalam melaksanakan proses pembangunannya. Namun demikian, sumber daya alam saja tidak menjamin keberhasilan proses pembanguan ekonomi, apabila tidak didukung oleh kemampaun sumber daya manusianya dalam mengelola sumber daya alam yang tersedia. Sumber daya alam yang dimaksud diataranya kesuburan tanah, kekayaan mineral, tambang, kekayaan hasil hutan dan kekayaan laut.

c. Faktor Ilmu Pengetahuan dan Teknologi

Perkembangan ilmu pengetahuan dan teknologi yang semakin pesat mendorong adanya percepatan proses pembangunan, pergantian pola kerja yang semula menggunakan tangan manusia digantikan oleh mesin-mesin canggih berdampak kepada aspek efisiensi, kualitas dan kuantitas serangkaian aktivitas pembangunan ekonomi yang dilakukan dan pada akhirnya berakibat pada percepatan laju pertumbuhan perekonomian.

d. Faktor Budaya

Faktor budaya memberikan dampak tersendiri terhadap pembangunan ekonomi yang dilakukan, faktor ini dapat berfungsi sebagai pembangkit atau pendorong proses pembangunan tetapi dapat juga menjadi penghambat pembangunan. Budaya yang dapat mendorong pembangunan diantaranya sikap kerja keras dan kerja cerdas, jujur, ulet dan sebagainya. Adapun budaya yang dapat menghambat proses pembangunan diantaranya sikap anarkis, egois, borosdan sebagainya.

e. Sumber Daya Modal

Sumber daya modal dibutuhkan manusia untuk mengolah SDA dan meningkatkan kualitas 
IPTEK. Sumber daya modal berupa barangbarang modal sangat penting bagi perkembangan dan kelancaran pembangunan ekonomi karena barang-barang modal juga dapat meningkatkan produktivitas.

\section{Ciri-Ciri Pertumbuhan Ekonomi}

a. Laju Pertumbuhan Penduduk Dan Produk Per Kapita

Pertumbuhan ekonomi modern, sebagaimana terungkap dari pengalaman negara maju sejak akhir abad ke-18 atau awal abad ke-19, ditandai dengan laju kenaikan produk per kapita yang tinggi dibarengi dengan laju pertumbuhan penduduk yang cepat. Laju kenaikan yang luar biasa itu paling sedikit sebesar lima kali untuk penduduk dan paling sedikit sepuluh kali untuk produksi.

b. Peningkatan Produktivitas

Pertumbuhan ekonomi modern terlihat dari semakin meningkatnya laju produk per kapita terutama sebagai akibat adanya perbaikan kualitas input yang meningkatkan efisiensi atau produktifitas per unit input. Hal ini dapat dilihat dari semakin besarnya masukan sumber tenaga kerja dan modal atau semakin meningkatnya efisiensi atau kedua-duanya. Kenaikan efisiensi berarti penggunaan output yang lebih besar untuk setiap unit input.

c. Laju Perubahan Struktural yang Tinggi.

Perubahan struktural dalam pertumbuhan ekonomi modern mencakup peralihan dari kegiatan pertanian ke non-pertanian, dari industri ke jasa, perubahan dalam skala unit-unit produktif, dan peralihan dari perusahaan perseorangan menjadi perusahaan terhadap hukum serta perubahan status kerja buruh.

d. Urbanisasi

Pertumbuhan ekonomi modern ditandai pula dengan semakin banyaknya penduduk negara maju yang berpindah dari daerah pedesaan ke daerah perkotaan.Inilah yang disebut urbanisasi.Urbanisasi pada umumnya merupakan produk industrialisasi.Skala ekonomi yang timbul dalam usaha nonagraris sebagai hasil perubahan teknologi menyebabkan perpindahan tenaga kerja dan penduduk secara besar-besaran dari pedesaan ke daerah perkotaan.Karena sarana teknis transportasi, komunikasi dan organisasi berkembang menjadi lebih efektif, maka terjadilah penyebaran unit-unit skal optimum. Semua proses ini memengaruhi pengelompokan penduduk berdasarkan status sosial dan ekonomi serta mengubah pola dasar perilaku kehidupan.

e. Ekspansi Negara Maju
Pertumbuhan negara maju kebanyakan tidak sama. Pada beberapa bangsa, pertumbuhan ekonomi modern terjadi lebih awal daripada bangsa yang lain. Hal ini sebagian besar disebabkan perbedaan latar belakang sejarah dan masa lalu.

f. Arus Barang, Modal, dan Orang Antar Bangsa Arus barang, modal, dan orang antarbangsa kian meningkat sejak kuartal kedua abad ke-19 sampai Perang Dunia I tetapi mulai mundur pada perang dunia I dan berlanjut sampai akhir perang dunia II. Namun demikian sejak awal tahun lima puluhan terjadilah peningkatan dalam arus barang, modal dan antarbangsa.

\section{Cara Menghitung Laju Pertumbuhan}

Data yang digunakan adalah data sekunder dariBadan Pusat Statistik (BPS) yang meliputi Produk DomestikRegional (PDR) atas dasar harga berlaku dan harga konstan. Produk Domestik Regional (PDR) merupakan salah satu indikator penting untuk mengetahui kondisi ekonomi di suatu daerah dalam suatu periode tertentu, baik atas dasar harga berlaku maupun atas dasar harga konstan. PDR pada dasarnya merupakan jumlah nilai tambah yang dihasilkan oleh seluruh unit usaha dalam suatu daerah tertentu, atau merupakan jumlah nilai barang dan jasa akhir yang dihasilkan oleh seluruh unit ekonomi pada suatu daerah.PDR atas dasar harga berlaku menggambarkan nilai tambah barang dan jasa yang dihitung menggunakan harga pada tahun berjalan, sedang PDR atas dasar harga konstan menunjukkan nilai tambah barang dan jasa tersebut yang dihitung menggunakan harga yang berlaku pada satu tahun tertentu sebagai tahun dasar. PDR menurut harga berlaku digunakan untuk mengetahui kemampuan sumber daya ekonomi, pergeseran, dan struktur ekonomi suatu daerah. Sementara itu, PDRkonstan digunakan untuk mengetahui pertumbuhan ekonomi secara riil dari tahun ke tahun atau pertumbuhan ekonomi yang tidak dipengaruhi oleh faktor harga. Perubahan PDB merupakan perubahan kuantitas output produksi secara riil. Ini yang sering disebut dengan "Pertumbuhan Ekonomi" yang mengacu pada peningkatan nilai total barang dan jasa yang diproduksi dalam sebuah perekonomian.

Rumus menghitung pertumbuhan ekonomi adalah sebagai berikut :

$$
\begin{aligned}
& \mathrm{g}=\{(\text { PDBs }- \text { PDBk })/ \text { PDBk }\} \times 100 \% \\
& \text { dimana }: \\
& \mathrm{g} \quad=\text { tinkat pertumbuhan ekonomi } \\
& \text { PDBs }=\text { PDB riil tahun sekarang }
\end{aligned}
$$




$$
\mathrm{PDBk}=\mathrm{PDB} \text { riil tahun kemarin }
$$

\section{Pertanian}

Pertanian secara umum adalah suatu kegiatan manusia dalam memanfaatkan sumber daya hayati untuk dapat menghasilkan bahan pangan, sumber energi, bahan baku industri dan untuk mengelola lingkungannya.Semua usaha pertanian pada dasarnya adalah kegiatan ekonomi, sehingga memerlukan dasar-dasar pengetahuan yang samaakan pengelolaan tempat usaha, pemilihan benih/bibit, metodebudidaya, pengumpulan hasil, distribusi produk, pengelolaan dan pengemasan produk dan pemasaran. Apabila semua petani memandang semua aspek ini dengan pertimbangan efisiensi untuk mencapai keuntungan maksimal maka bisa dikatakan melakukan pertanian intensif (intensive farming). Usaha pertanian yang dipandang dengan cara ini dikenal sebagai agribisnis. Program dan kebijakan yang mengarahkan usaha pertanian secara pandang demikian dikenal sebagai intensifikasi. Sedangkan pertanian secara luas adalah kegiatan pemanfaatan sumber daya hayati yang dilakukan oleh manusia dengan cara mananamtanaman produktif yang dapat menghasilkan bahan pangan, bahan baku industri, atau sumber energi, serta untuk mengelola lingkungan hidup yang dipergunakan untuk kehidupan manusia.Dalam pengertian lain pertanian ialah pengeluaran makanan dan barang melalui perladangan, peternakan, dan perhutanan yang hasilnya dapat mencukupi kebutuhan manusia.

\section{Sektor Industri}

Kebanyakan orang mengasumsikan bahwa industri hanyalah kegiatan ekonomi manusia yang mengolah bahan baku/bahan mentah menjadi barang setengah jadi atau bahan jadi. Padahal pengertian industri sangatlah luas, proses industri ini meliputi semua kegiatan manusia dalam suatu bidang tertentu yang sifatnya produktif dan komersial. Kata industri berasal dari bahasa Francis kuno yaitu "industrie" yang berarti aktivitas, tetapi kata tersebut dasarnya berasal dari bahasa latin yaitu "Industria" yang memiliki arti kerajinan dan aktivitas. Dalam arti luas industri adalah suatu bidang yang bersifat komersial yang menggunakan keterampilan kerja serta teknologi untuk menghasilkan suatu produk dengan tujuan mendapatkan keuntungan.Jadi Industri adalah bidang yang menggunakan keterampilan, dan ketekunan kerja dan penggunaan alat-alat di bidang pengolahan hasil-hasil bumi, dan distribusinya sebagai dasarnya. Maka industri umumnya dikenal sebagai mata rantai selanjutnya dari usaha-usaha mencukupi kebutuhan (ekonomi) yang berhubungan dengan bumi, yaitu sesudah pertanian, perkebunan, dan pertambangan yang berhubungan erat dengan tanah. Kedudukan industri semakin jauh dari tanah, yang merupakan basis ekonomi, budaya, dan politik.Bidang industri dibedakan menjadi dua, yaitu industri barang dan industri jasa.

\section{Sektor Jasa}

Dalam ilmu ekonomi, jasa atau layanan adalah aktivitas ekonomi yang melibatkan sejumlah interaksi dengan konsumen atau dengan barang-barang milik, tetapi tidak menghasilkan transfer kepemilikan. Sektor jasa dapat dikelompokkan dalam bebebrapa bidang jasa, antara lain:

a. Jasa dibidang bisnis (business service), seperti konsultasi jasa-jasa keuangan dan perbankan.

b. Jasa dibidang perdagangan (distribution service), seperti jasa-jasa perdagangan eceran, grosir, jasajasa pemeliharaan dan perbankan.

c. Jasa di bidang infrastruktur (infrastructure service). Seperti jasa-jasa komunikasi dan transportasi.

d. Jasa untuk kepentingan sosial dan pribadi (social and personal service), seperti rumah sakit, restoran, dan salon kecantikan.

e. Jasa adminitrasi pemerintahan (government service), seperti jasa pendidikan, dan pemerintahan militer (militer, polisi dan pengadilan).

f. Jasa pariwisata sebagai penghasil devisa, meratakan dan meningkatkan kesempatan kerja dan pendapatan, memperkokoh persatuan dan kesatuan, serta budaya bangsa.

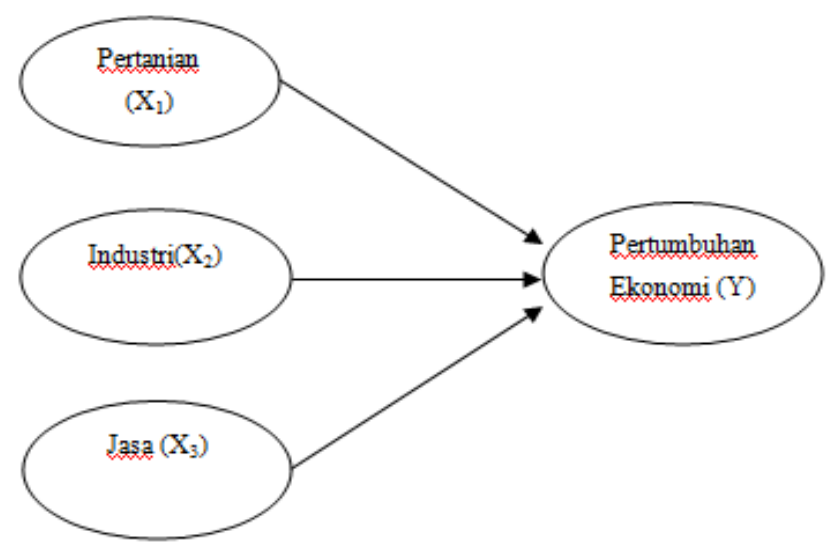

Gambar 1. Kerangka Konseptual

Berdasarkan kerangka konseptal diatas adapun hipotesis yang diajukan dalam penelitian ini adalah:

1. Diduga bahwa sektor pertanian berpengaruh positif dan signifikan terhadap pertumbuhan ekonomi. 
2. Diduga bahwa sektor industri berpengaruh positif dan signifikan terhadap pertumbuhan ekonomi.

3. Diduga bahwa sektor jasa berpengaruh positif dan signifikan terhadap pertumbuhan ekonomi

\section{METODE}

Jenis data yang digunakan dalam penelitian adalah data kuantitatif yaitu data yang disusun secara sistematis, terencana dan memiliki rincian angka, yang diperoleh dari objekpenelitian yang berhubungan dengan masalah yang diteliti.Sumber data yang digunakan dalam penelitian ini adalah data sekunder. Data sekunder adalah data yang dikumpulkan secara tidak langsung dari sumbernya. Data sekunder biasanya dikumpulkan oleh lembaga pengumpul data dan dipublikasikan kepada masyarakat pengguna data (Sugiyono,2002). Data penelitian ini diperoleh dari jurnal, skripsi dan bukubuku referensi maupun data dari instansi-instansi terkait materi pembahasan.

\section{HASIL DAN PEMBAHASAN}

Hasil Analisis Data

\section{Sektor Pertanian}

Tabel 4.1. Pendapatan Pertanian

\begin{tabular}{|c|c|c|c|}
\hline No. & Tahun & $\begin{array}{c}\text { Pendapatan } \\
\text { Pertanian (Jutaan) }\end{array}$ & Persen \\
\hline 1. & 2011 & $631.765,700$ & $-5,06$ \\
\hline 2. & 2012 & $657.201,100$ & 4,03 \\
\hline 3. & 2013 & $695.638,100$ & 5,85 \\
\hline 4. & 2014 & $753.097,300$ & 8,26 \\
\hline 5. & 2015 & $755.647,600$ & 0,34 \\
\hline
\end{tabular}

Sumber: Badan Pusat Statistik (BPS) Kota Palopo

Berdasarkan tabel 4.1 diketahui bahwa pendapatan pertanian di Kota Palopo selama 5 tahun terakhir dari tahun 2011-2015 mengalami peningkatan secara terus menerus, walaupun pada tahun 2011 sempat mengalami penurunan sebesar -5,06.Akan tetapi,di tahun 2012 mengalami peningkatan sebesar 4,03\% dan pada tahun 2013-2014 mengalami peningkatan tertinggi sebesar 8,26\%, dan pada tahun 2015 mengalami penurunan dengan hanya memberikan konstribusisebesar $0,34 \%$.

\section{Sektor Industri.}

Tabel 4.2. Pendapatan Industri

\begin{tabular}{|c|c|c|c|}
\hline No. & Tahun & $\begin{array}{c}\text { Pendapatan Industri } \\
\text { (Jutaan) }\end{array}$ & Persen \\
\hline 1. & 2011 & $98.274,200$ & 4,80 \\
\hline 2. & 2012 & $99.772,500$ & 1,47 \\
\hline 3. & 2013 & $103.615,300$ & 3,90 \\
\hline 4. & 2014 & $109.553,800$ & 5,73 \\
\hline 5 & 2015 & $115.276,000$ & 5,22 \\
\hline
\end{tabular}

Sumber: Badan Pusat Statistik (Kota Palopo)

Pada tabel 4.2 dapat diketahui bahwa kontribusi industri terhadap pertumbuhan ekonomi pada tahun 2011-2012 mengengalami penurunan sebesar 1,47\%, pada tahun 2013 mengalami peningkatan sebesar $3,90 \%$ dan secara terus menerus mengalami peningkatan dimana pada tahun 2014 kontribusinya sebesar 5,73\% dan 2015 sebesar 5,22\%.

\section{Sektor Jasa}

Tabel 3. Pendapatan Jasa

\begin{tabular}{|c|c|c|c|}
\hline No & Tahun & $\begin{array}{c}\text { Pendapatan jasa } \\
\text { (Jutaan) }\end{array}$ & Persen \\
\hline 1. & 2011 & $520.170,900$ & 13,16 \\
\hline 2. & 2012 & $566.734,700$ & 13,25 \\
\hline 3. & 2013 & $613.513,700$ & 13,33 \\
\hline 4. & 2014 & $637.834,700$ & 13,37 \\
\hline 5. & 2015 & $683.191,100$ & 13,43 \\
\hline
\end{tabular}

Sumber: Badan Pusat Statistik (Kota Palopo)

Pada tabel 4.4 di atas dapat diketahui bahwa angka pendapatan dari sektor jasa yang terdapat pada tabel diatas adalah penjumlahan dari berbagai jenis usaha jasa seperti jasa keuangan dan asuransi, jasa perusahaan, jasa pendidikan, jasa kesehatan dan kegiatan sosial, serta jasa lainnya dengan angka persen yang sudah di log naturalkan.Jadi, bisa dilihat dimana pada tahun 2011-2015 secara terus menerus mengalami peningkatan. 


\section{Hasil Analisis Regresi Berganda}

Tabel 4.Model Regresi dan Pengujian Hipotesis

\begin{tabular}{|c|c|c|c|c|c|}
\hline \multirow[t]{2}{*}{ Model } & \multicolumn{2}{|c|}{$\begin{array}{l}\text { Unstandardized } \\
\text { Coefficients }\end{array}$} & \multirow{2}{*}{$\begin{array}{c}\begin{array}{c}\text { Standardized } \\
\text { Coefficients }\end{array} \\
\text { Beta }\end{array}$} & \multirow{2}{*}{$\mathrm{T}$} & \multirow[b]{2}{*}{ Sig. } \\
\hline & B & $\begin{array}{c}\text { Std. } \\
\text { Error }\end{array}$ & & & \\
\hline (Constant) & -1.872 & .091 & & -20.484 & .031 \\
\hline LN Pertanian & .268 & .017 & .194 & 16.039 & .040 \\
\hline LN Industri & .426 & .018 & .257 & 23.802 & .027 \\
\hline LN Jasa & 586 & .012 & .561 & 48.521 & .013 \\
\hline
\end{tabular}

Untuk mengetahui pengaruh pertanian, industri dan jasa terhadap pertumbuhan ekonomi Di Kota Palopo dalam penelitian ini menggunakan metode analisis regresi linier berganda.

Analisis regresi linier berganda dengan formulasi sebagai berikut: (Sugiyono, 2012)

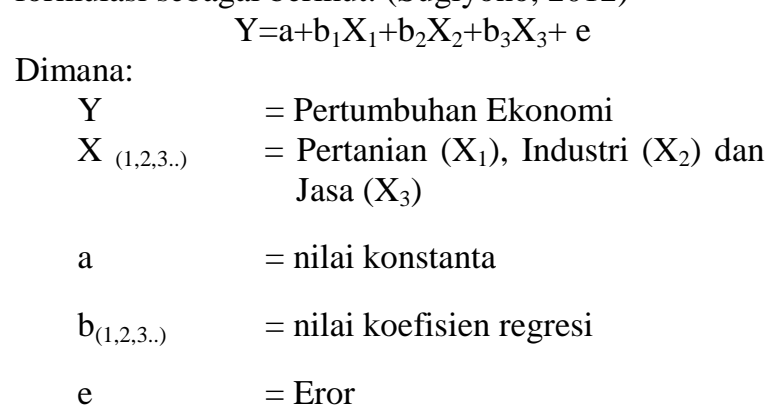

Berdasarkan hasil analisis pada tabel 4.7 di atas maka model regresi untuk menguji pengaruh pertanian, industri dan jasa terhadap pertumbuhan ekonomi Di Kota Palopo selama periode 2011-2015 adalah sebagai berikut:

$$
\mathrm{Y}=-1.872+0.268 \mathrm{X}_{1}+0.426 \mathrm{X}_{2}+0.586 \mathrm{X}_{3}
$$

Interpretasi dari model analisis regresi di atas yaitu nilai konstanta (a) diperoleh sebesar -1.872 artinya adalah apabila variabel pertanian, industri dan jasa pada pertumbuhan ekonomi Di Kota Palopo adalah konstan atau sama dengan nol (0), maka pertumbuhan ekonomi di Kota palopo selama periode 2011-2015 mengalami penurunan sebesar -1.872. Nilai koefisien regresi variabel pertanian sebesar 0,268 satuan, hal ini dapat diartikan bahwa setiap peningkatan pendapatan sektor pertanian sebesar 0,268 akan meningkatan pertumbuhan ekonomi Di KotaPalopo sebesar satu satuan. Nilai koefisien regresi variabel industri sebesar 0,426 satuan, hal ini dapat diartikan bahwa setiap peningkatan pendapatan sektor industri sebesar 0,426 akan meningkatkan pertumbuhan ekonomi Di Kota Palopo sebesar satuan satuan. Nilai koefisien regresi variabel jasa sebesar 0,586 satuan, hal ini dapat diartikan bahwa setiap peningkatan pendapatan sektor jasa sebesar 0,586 akan meningkatkan pertumbuhan ekonomi Di Kota Palopo sebesar satu satuan.

\section{Uji Signifikan Parsial (Uji-t)}

Uji $\mathrm{t}$ dilakukan untuk mengetahui pengaruh secara parsial variabel independenterhadapvariabel dependen.Derajatsignifikansi yang digunakan adalah 0,05 . Apabila nilai signifikan lebih kecil dari derajat kepercayaan maka kita menerima hipotesis alternatif, yang menyatakan bahwa suatu variabel independen berpengaruh terhadap variabel dependen.

a) Pengaruh dari pertanian terhadap pertumbuhan ekonomi Di Kota Palapo dapat dilihat dari arah tanda dan tingkat signifikansi. Hasil pengujian parsial (uji t) antara pertanian terhadap pertumbuhan ekonomi menunjukkan nilai t hitung sebesar 16,039koefisien regresi sebesar 0,194 dan nilai (sig) sebesar 0,04 yang tidak lebih besar dari 0,05 hal ini berarti bahwa Pertanian berpengaruh positif terhadap Pertumbuhan Ekonomi Di Kota Palopo.

b) Pengaruh dari industri terhadap pertumbuhan ekonomi Di Kota Palapo dapat dilihat dari arah tanda dan tingkat signifikansi. Hasil pengujian parsial (uji t) antara pertanian terhadap pertumbuhan ekonomi menunjukkan nilai t hitung sebesar 23,802koefisien regresi sebesar 0,257 dan nilai (sig) sebesar 0,027 yang tidak lebih besar dari 0,05 hal ini berarti bahwa Industri berpengaruh positif terhadap Pertumbuhan Ekonomi Di Kota Palopo.

c) Pengaruh dari sektor jasa terhadap pertumbuhan ekonomi Di Kota Palapo dapat dilihat dari arah tanda dan tingkat signifikansi. Hasil pengujian parsial (uji t) antara pertanian terhadap pertumbuhan ekonomi menunjukkan nilai t hitung sebesar 48,521koefisien regresi sebesar 0,561 dan nilai (sig) sebesar 0,013 yang tidak lebih besar dari 0,05 hal ini berarti bahwa sektor jasa berpengaruh positif terhadap Pertumbuhan Ekonomi Di Kota Palopo.

\section{Koefisien Determinasi}

Uji ini dilakukan untuk mengukur kemampuan variabel-variabel indepeden, hasil koefisien determinasi dapat dilihat pada kolom adjusted $\mathrm{R}$ square, yang ditampilkan pada tabel berikut.

Tabel 5. Koefisiensi Determinasi

\begin{tabular}{|l|l|r|r|l|}
\hline Model & $\mathrm{R}$ & $\begin{array}{l}\mathrm{R} \\
\text { Square }\end{array}$ & $\begin{array}{l}\text { Adjusted } \\
\text { R Square }\end{array}$ & $\begin{array}{l}\text { Std. Error } \\
\text { of } \\
\text { theEstimate }\end{array}$ \\
\hline 1 & $902^{\mathrm{a}}$ & 1.000 & .820 & .00064 \\
\hline
\end{tabular}


Angka $\mathrm{R}$ yang di dapat pada tabel adalah sebesar 0,902 artinya korelasi antara Variabel Pertanian, industry dan Jasa dengan Variabel Pertumbuhan Ekonomi sebesar 0,902. Hal ini berarti terjadi hubungan yang sangat erat karena nilainya mendekati 1. Adjust $\mathrm{R}$ Square, adalah $\mathrm{R}$ square yang telah disesuaikan nilai sebesar 0,820 ini juga menunjukkan sumbangan pengaruh variabel independen terhadap variabel dependen. Adjust R Square biasanya untuk mengukur sumbangan pengaruh Pertanian, Industri, dan Jasa sebesar $82,0 \%$ dan sisanya $18,0 \%$ dipengaruhi oleh variabel lain. Untuk standard eror of the estimate, adalah ukuran kesalahan prediksi, nilai sebesar 0,00064 artinya kesalahan dalam memprediksi sebesar $0,064 \%$.

\section{Pengujian Simultan (Uji f)}

Pengujian ini dilakukan untuk mengetahui pengaruh seluruh variabel independen secara bersama-asama atau simultan terhadap variabel dependen dengan menggunakan uji $\mathrm{F}$ dengan tarif signifikan 5\%.Jika nilai signifikan uji $\mathrm{F}$ lebih kecil dari 5\% maka terdapat pengaruh antara semua variabel independen terhadap variabel dependen. Hasil pengujian uji $\mathrm{F}$ dapat di lihat pada tabel berikut ini :

Tabel 6. Hasil Pengujian Simultan (Uji f)

\begin{tabular}{|l|c|c|c|c|c|}
\hline Model & $\begin{array}{c}\text { Sum of } \\
\text { Squares }\end{array}$ & Df & $\begin{array}{c}\text { Mean } \\
\text { Square }\end{array}$ & F & Sig. \\
\hline Regression & .049 & 3 & .016 & 39853.005 & $.004^{\mathrm{b}}$ \\
\hline 1 & .000 & 1 & .000 & & \\
Residual & .049 & 4 & & & \\
\hline Total & .049 & & \\
\hline
\end{tabular}

Dari tabel 4.9 di atas diketahui uji $\mathrm{F}$ menunjukkan bahwa $\mathrm{F}$ hitung adalah 39853,005 dengan tingkat signifikansi 0,004 . karena tingkat signifikan lebih kecil dari $\alpha(0,004 \leq 0,05)$ maka $\mathrm{H}_{1}$ diterima. Dengan demikian dapat disimpulkan bahwa variabel independen dalam penelitian ini (simultan) berpengaruh signifikan terhadap variabel dependen. Hal ini berarti jika Pertanian $\left(\mathrm{X}_{1}\right)$, Industri $\left(\mathrm{X}_{2}\right)$ dan $\operatorname{Jasa}\left(\mathrm{X}_{3}\right)$ meningkat, maka Pertumbuhan Ekonomi (Y) juga akan meningkat. Dan sebaliknya, jika pertanian, industri dan jasamenurun, maka pertubuhan ekonomi juga akan menurun.

\section{PENUTUP}

Berdasarkan pembahasan hasil penelitian, maka dapat ditarik kesimpulan bahwa :

1. Berdasarkan uji $\mathrm{R}$ diatas sektor pertanian, industri, dan jasa berpengaruh signifikan terhadap peningkatan pertumbuhan ekonomi Di Kota Palopo yaitu sebesar 0,820

2. Berdasarkan uji F bahwa sektor pertanian, industri dan jasa berpengaruh signifikan terhadap peningkatan pertumbuhan ekonomi Di Kota
Palopo yakni bahwa F hitung adalah 39853,005 dengan tingkat signifikansi 0,004 .

3. Berdasarakan pengujian parsial (uji t) antara pengaruh pertanian, industri dan jasa terhadap peningkatan pertumbuhan ekonomi Di Kota Palopo menunjukkan nilai t hitung pertanian $\left(\mathrm{X}_{1}\right)$ sebesar 16,039 koefisien regresi sebesar 0,194 dan nilai (sig) sebesar 0,04.Nilai $\mathrm{t}$ hitung industri $\left(\mathrm{X}_{2}\right)$ sebesar 23,802 koefisien regresi sebesar 0,257 dan nilai (sig) sebesar 0,027. Dan pada $\mathrm{jasa}\left(\mathrm{X}_{1}\right)$ nilai t hitungnya sebesar 48,521 koefisien regresi sebesar 0,561 dan nilai (sig) sebesar 0,013 dimana ketiga sektor nilai signifikan tidak lebih besar dari 0,05 hal ini berarti bahwa pertanian, industri, dan jasa berpengaruh positif terhadap peningkatan pertumbuhan ekonomi Di Kota Palopo.

Berdasarkan hasil penelitian yang telah dilakukan, maka peneliti dapat mengemukakan saran yaitu dari hasil penelitian yang telah dilakukan bahwa pertanian, industri dan jasa signifikan terhadap peningkatan pertumbuhan ekonomi. Oleh karna itu,PemerintahKota Palopo perlu meningkatkan dan lebih memperhatikan ketiga sektor ini sehingga pertumbuhan ekonomi terus meningkat dan dapat dirasakan oleh semua pihak baik itu pemerintah ataupun masyarakat.

\section{DAFTAR PUSTAKA}

Abdullah Faisal.M, 2002, DasardasarManajemenKeuangan,UniversitasMuha mmadiyah Malang.

Ahmad munawar.2005.Dasar-

DasarTeknikTransportasi.Jogjakarta.

BettaOfsite

Ananonim. 2008. Badan pusat statistik kota palopo dalam angka 2007. Palopo. Ananonim. 2008.

Badan pusat statistik penduduk dan tenaga kerja. Jakarta

Badan Perencanaan Pembangunan Kota Palopo: Renstra Kota Palopo: Publikasi BAPPEDA Palopo (2012)

Badan Pusat Statistik: Palopo dalam Angka. Palopo:Publikasi BPS Kota Palopo (2012)

Chelsea,Yuyun, 2012, Pengertian Ekonomi dan Perekenomian Indonesia.

Lincilon, 1993.A Dictionary of Economics.Inggris: Penguin Books Ltd.

MudrajadKuncoro. 2003. Metode Riset untuk bisnis dan Ekonomi. Jakarta: Erlangga 
M. L. Jhingan. 2013. Ekonomi Pembangunan Dan Perencanaan. Jakarta: PT. Raja grafindo Persada

Nasution M Nur. 2004. ManajemenTransportasi. Jakarta GhaliaIndonesia

Sadono. 1985. Pembangunan Kota dari Pendapatan Daerah: Jakarta

Sugiarto, Tedy Herlambang, Brastoro, Rahmat sudjana dan Said Kelana. 2002. Ekonomi Mikro: Sebuah Kajian Komprehensif. Jakarta: Penerbit PT. Gramedia Pustaka Utama

Sugiyono. 2002. Memahami Tentang Penjelasan Data Sekunder. Bandung:Alfabeta

Sugiyono. 2005. MemahamiPenelitianKualitatif. Bandung:Alfabeta

Sugiyono. 2008. Jawaban teoritis terhadap rumusan masalah penelitian. Bandung:Alfabeta

Sugiyono. 2009. MetodePenelitianKuantitatif, Kualitatif, dan R \& D. bandung: Alfabeta

Sugiyono. 2011. StatistikuntukPenelitian. Bandung : CV. Alfabeta

Sukirno, Sadono. 2011. Makroekonomi Teori Pengantar. Jakarta: PT. Raja GrafindoPersada. 